\title{
Exergy Analysis of Conventional and Low Exergy Systems for Heating and Cooling of Near Zero Energy Buildings
}

\author{
Mateja Dovjak ${ }^{1, *}$ - Masanori Shukuya ${ }^{2}$ - Aleš Krainer ${ }^{1}$ \\ 1 University of Ljubljana, Faculty of Civil and Geodetic Engineering, Slovenia \\ 2 Laboratory of Building Environment, Tokyo City University, Japan
}

The purpose of the study is to compare two heating and cooling $(\mathrm{H} / \mathrm{C})$ systems regarding individual thermal comfort conditions and rational building energy use. Real test room is firstly equipped with low exergy (LowEx) system (i.e. heating-cooling ceiling radiative panels) and secondly with a conventional system (i.e. electric heaters, cooling split system with indoor unit). Additional case presents a thermally noninsulated room equipped with a conventional system. Individual thermal comfort conditions are analyzed through the simulation of human body exergy balance ( $h b E x B$ ), human body exergy consumption ( $h b E x C$ ) rates and predicted mean votes (PMV) index. Measurements of energy use and control of temperature conditions are performed on an integrated control system (ICSIE) based on fuzzy logic. The results confirm that both systems create comfort conditions if the room is thermally well insulated. In case of non-insulated room there appears cool radiant exergy that often leads to discomfort conditions. More acceptable comfortable conditions (PMV closer to 0) do not always result in a lower hbExC rate. Individual characteristics with experimental conditions have a significant influence on separate parts of hbExB. LowEx system connected with ICSIE enables to set air temperature and mean radiant temperature and creates optimal thermal comfort conditions for individual user. The measured energy use for heating was by 11 to $27 \%$ lower for LowEx system than for the conventional system. The energy use for cooling was by 41 to $62 \%$ lower for LowEx system. The presented approach of reciprocal consideration of individual thermal comfort conditions and building energy use is important for the future design of $\mathrm{H} / \mathrm{C}$ systems and for their application in near zero energy buildings.

Keywords: human body exergy, building heating and cooling, low exergy system, conventional system, building energy use, individual thermal comfort

\section{O INTRODUCTION}

To reach the aim of near zero energy buildings according to the Directive 2010/31/EU [1] a new approach to solving problems related to high energy use has to be defined and realized. The most effective is a holistic approach that includes interventions in the building envelope together with efficient heating and cooling systems [2]. On the level of system efficiency besides energy use, thermal comfort of an individualj should also be regarded. Moreover, thermal comfort and productivity are more important than efficient energy use. The same is true when it comes to labour cost and operational costs of buildings. Rant [3] explained the difference between the terms energy and exergy back in 1955. The exergy concept has already been well applied in the analysis of the efficiency of thermal processes [4]. However, the use of exergy concept in a built environment related to thermal comfort is still relatively new. The exergy concept can be derived from two fundamental concepts, energy and entropy, and the concept of the environmental temperature. It can explicitly indicate how much exergy is consumed in a variety of natural phenomena going on inside and outside a built environment [5] and [6]. The study by Dovjak et al. [2] compared the results of exergy and energy analysis of the whole heating system in Slovenian buildings and defined the most effective solutions towards lower building energy use. Exergy analysis helps us to make connections among processes inside the human body and processes in a building [6] and leads to the design of heating and cooling systems that provide both thermal comfort conditions and rational building energy use [7].

In most public and residential buildings, conventional active systems using high value nonrenewable energy sources are used for heating and cooling $(\mathrm{H} / \mathrm{C})$. Nevertheless, on the market there also exist active low exergy systems (LowEx) that use low value energy sources such as renewable and other sustainable sources. They present lowtemperature heating and high-temperature cooling systems. Currently there are many different LowEx technologies available that could be classified as surface heating and cooling systems (i.e. floor, ceiling, wall $\mathrm{H} / \mathrm{C}$ systems), air heating and cooling systems (e.g. recuperators), generation/conversion of cold and heat (e.g. heat pump, sun collectors), thermal storage (e.g. seasonal storage wall), distribution (e.g. district $\mathrm{H} / \mathrm{C}$ ) [8] to [11]. The paper is focused on large surface $\mathrm{H} / \mathrm{C}$ systems $(\mathrm{H} / \mathrm{C}$ radiative panels). LowEx systems have many advantages in comparison with conventional $\mathrm{H} / \mathrm{C}$ systems. The most important advantages are the improvement of comfort conditions [12] to [14], the reduction of energy use for heating and cooling of buildings [12] to [15] and improved indoor air quality due to higher relative humidity 
of air, a higher number of air changes, and lower concentration of mites [6], [14], [16] and [17].

Experiences of architects and engineers working with the design of comfort conditions in winter show that higher surface temperature $\left(T_{m r}\right)$ and lower air temperature $\left(T_{a i}\right)$ can result in more comfortable conditions. This coincides with the fact that comfort conditions seem to lead to lower exergy consumption of human body. The relation was first investigated by Isawa et al. [18], Shukuya [19] and [21], Shukuya et al. [20], and Prek [22] and [23]. Simone et al. [24] studied the relation between the human body exergy consumption rate and the human thermal sensation. The results [24] showed that the minimum human body exergy consumption rate was related to the thermal sensation votes close to thermal neutrality, tending to a slightly cooler side of thermal sensation. The whole human body exergy balance under typical summer conditions in hot and humid regions was analyzed by Iwamatsu and Asada [25] and Shukuya et al. [20]. Tokunaga and Shukuya [26] investigated the human-body exergy balance calculation under un-steady state conditions. Schweiker and Shukuya [27] compared the predicted mean vote approach, the adaptive comfort model and the calculation of the human body exergy consumption rate by three distinctive procedures. So far only the human body exergy consumption for an average man or a larger group have been considered, but not of an individual user. Indeed, there is no study where the comparison between LowEx and conventional system is based upon the whole human body exergy balance and measured energy use in building. Moreover, the presented study presents an upgrade of the study by Dovjak et al. [2].

From the exergetic point of view, the comparison between conventional and LowEx systems regarding simulated thermal comfort conditions for individual user and measured building energy use will be investigated. The presented approach of reciprocal consideration of individual thermal comfort conditions and building energy use is important for the future design of $\mathrm{H} / \mathrm{C}$ systems and for their application in near zero energy buildings.

\section{METHOD}

\subsection{Exergy-Entropy Processes in Human Beings}

All natural or human made processes, such as biochemical processes inside the human body or any technological process, present exergy-entropy processes. Their main characteristics are generation of exergy, consumption of exergy, entropy generation and entropy disposal. The general form of exergy balance equation for the human body as a system is expressed as follows [20]:

$$
\begin{gathered}
\text { [Exergy input }]-[\text { Exergy consumption }]= \\
=[\text { Exergy stored }]+[\text { Exergy output }] .
\end{gathered}
$$

To maintain comfort and healthy conditions, it is important that exergy consumption and stored exergy are at optimal values with a rational combination of exergy input and output. The exergy input consists of five components: 1) warm exergy generated by metabolism; 2) warm/cool and wet/dry exergies of the inhaled humid air; 3) warm and wet exergies of the liquid water generated in the core by metabolism; 4) warm/cool and wet/dry exergies of the sum of liquid water generated in the shell by metabolism and dry air to let the liquid water disperse; 5) warm/cool radiant exergy absorbed by the whole skin and clothing surfaces.

The exergy output consists of four components: 1) warm and wet exergy contained in the exhaled humid air; 2) warm/cool and wet/dry exergy contained in resultant humid air containing the evaporated sweat; 3) warm/cool radiant exergy discharged from the whole skin and clothing surfaces; and 4) warm/ cool exergy transferred by convection from the whole skin and clothing surfaces into the surrounding air [20].

\subsection{Experimental Set Up}

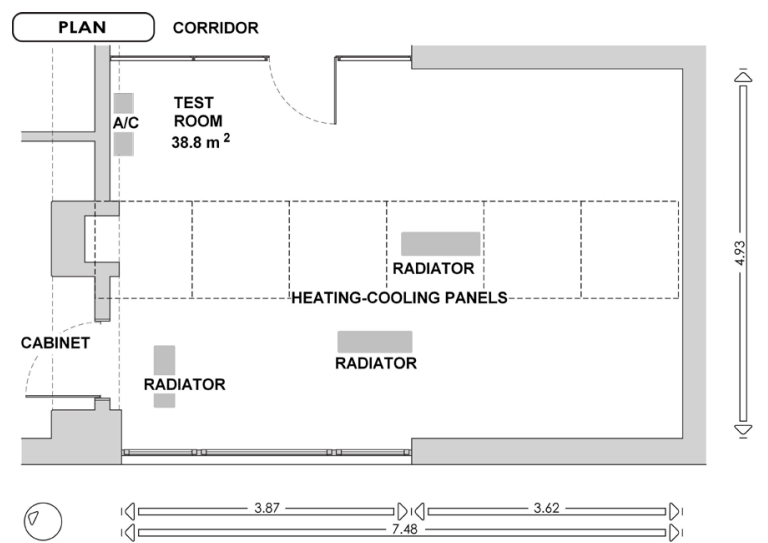

Fig. 1. Plan of test room with positions of conventional system (oil-filled electric heaters and split system with indoor A/C unit) and LowEx system (heating and cooling panels)

Test room $\left(163.4 \mathrm{~m}^{3}\right)$ has one exterior wall with $15 \mathrm{~m}^{2}$ glazed window; other walls are interior. It is located at the Chair for Buildings and Constructional Complexes, Faculty of Civil and Geodetic 
Engineering, University of Ljubljana, and equipped with LowEx and conventional system for heating and cooling with time separation. The conventional system includes 3 oil filled electric heaters and split system with indoor $\mathrm{A} / \mathrm{C}$ unit. LowEx system includes six low-temperature-heating and high-temperaturecooling ceiling radiative panels (Fig. 1).

The final layer of four panels is a contact stuck $1.25 \mathrm{~cm}$ gypsum board, and two panels have stone plates (one is a compact $2 \mathrm{~cm}$ marble plate and another a composite $12 \mathrm{~mm}$ Al-honeycomb with $3 \mathrm{~mm}$ tick stone plate). All panels are fixed with 4 steel screws into ceiling construction (Fig. 2).

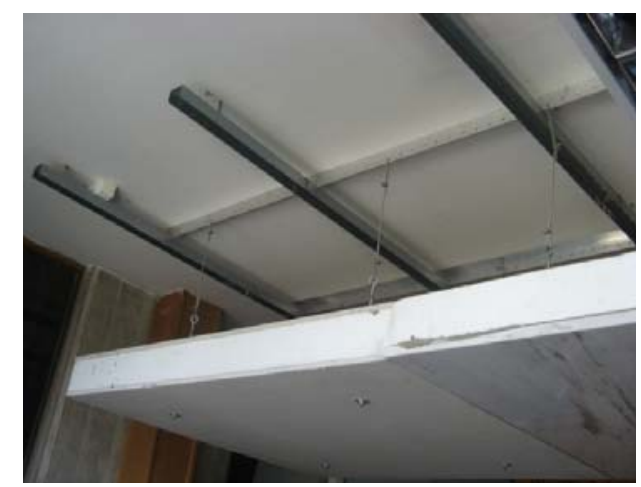

Fig. 2. $\mathrm{H} / \mathrm{C}$ radiative ceiling panels with panel assembly

Panels are connected into $\mathrm{H} / \mathrm{C}$ system with valves for switching off every panel separately, and with a pump on thermostatic mixing valve. Switching between hot and cool water entering into the panels is manual. Plan and section of panels are presented in Fig. 3.
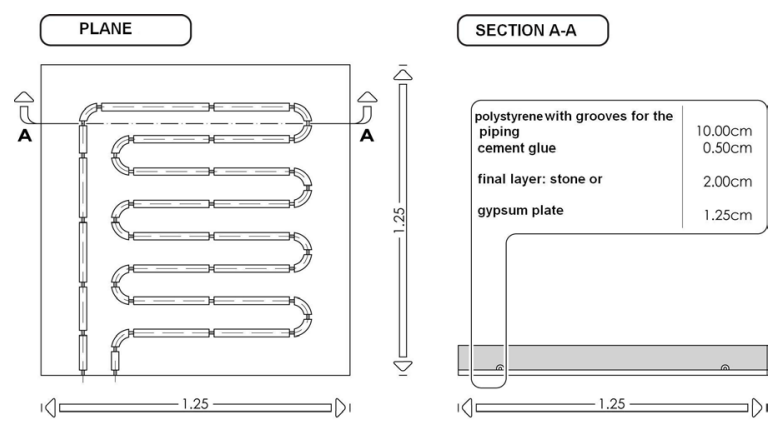

Fig. 3. Plan and section of H/C LowEx panels; in the plan the grooves for the piping are shown

The systems were compared regarding simulation of individual thermal comfort conditions and measured energy use. Two virtual users (hereinafter called users) were simulated for the analysis of individual thermal comfort conditions.
Users' characteristics are presented in Table 1. In the simulation users were exposed to experimental conditions based on in-situ real-time measurements (Table 2). In the case of conventional system $T_{a i}$ was equal to $T_{m r}$. In the case of LowEx system $T_{a i}$ differed from $T_{m r}$. All combinations of $T_{a i}$ and $T_{m r}$ result in the same $T_{o}\left(22.5^{\circ} \mathrm{C}\right)$. An additional case for simulation is a hypothetical test room with non-insulated building envelope. Skin temperature $\left(T_{s k}\right)$, body core temperature $\left(T_{c r}\right)$ and clothing temperature $\left(T_{c l}\right)$ were calculated considering experimental conditions. $R H_{\text {in }}$ was set at $60 \%$. Experimental conditions in Table 2 present one of the selected conditions for simulation. However, LowEx connected with an integrated control system of internal environment on the basis of fuzzy logic (ICsIE) enables to set up different combinations between $T_{a i}$ and $T_{m r}$ as it will be presented in continuation. Individual thermal comfort conditions are analyzed by calculated human body exergy balance (hbExB), human body exergy consumption $(\mathrm{hbExC})$ rates and predicted mean votes $(P M V)$ index with spread sheet software developed by Hideo Asada Rev 2010 [20] and [25]. The human body is treated as a thermodynamic system of core and shell, based on exergy-entropy processes. The calculation procedures follow the human body exergy model by Shukuya et al. [20]. The software enables to calculate the whole hbExB (input, output, stored and consumed exergy rates, $P M V, T_{c l}, T_{s k}, T_{c r}$ ) based on input data. Input data are outdoor and indoor experimental conditions $\left(T_{a i}, T_{a o}, T_{m r}, R H_{\text {in }}, R H_{\text {out }}\right)$, individual data (met, clo), and room dimensions. For exergy calculations, the reference environmental temperature (the outdoor environmental temperature, $T_{a o}$ ) and $R H_{o u t}$ are set at to be equal to $T_{a i}$ and $R H_{i n}$. Energy use for $\mathrm{H} / \mathrm{C}, T_{\text {ao }}$, $T_{a i}, T_{m r}, R H_{\text {in }}$ and $R H_{\text {out }}$ are continuously monitored with ICsIE system. ICsIE system was developed by Trobec-Lah [29] and upgraded by Košir [28], Košir et al. [30], and Kristl et al. [31]. It enables the control of indoor air temperature, $\mathrm{CO}_{2}$ and illuminance under the influence of outdoor environment and users' requests. In such a way, LowEx system connected with ICsIE enables to set up different combinations of $T_{a i}$ and $T_{m r}$. The ICsIE system is divided in three parts: the sensor network system, the regulation system and the actuator system. The basic architecture of the system is presented in Fig. 4. Since energy use was measured for the same space equipped with LowEx and conventional system in different periods, approximately the same conditions were selected for the systems' comparison (equal set-point $T$, time period, $T_{a o}$ and $T_{a i}$ variate among systems $\pm 1.0 \mathrm{~K}$; $0.8 \%$ assumed error). 
Table 1. User characteristics

\begin{tabular}{|c|c|c|c|c|c|c|c|c|}
\hline User & Gender & Age & $\begin{array}{c}A_{d u} \\
{\left[\mathrm{~m}^{2}\right]}\end{array}$ & $\begin{array}{l}\text { Met. } \\
\text { rate } \\
\text { [met] }\end{array}$ & $\begin{array}{c}\text { Eff. clo. } \\
\text { ins. } \\
\text { [clo] }\end{array}$ & $\begin{array}{c}T_{c r} \\
{\left[{ }^{\circ} \mathrm{C}\right]}\end{array}$ & $\begin{array}{c}T_{s k} \\
{\left[{ }^{\circ} \mathrm{C}\right]}\end{array}$ & $\begin{array}{c}T_{c l} \\
{\left[{ }^{\circ} \mathrm{C}\right]}\end{array}$ \\
\hline 1 & Male & 30 & 1.9 & 1.1 & 0.6 & $\begin{array}{c}36.8 \\
\text { to } \\
36.9 \\
\end{array}$ & $\begin{array}{c}33.4 \\
\text { to } \\
34.3 \\
\end{array}$ & $\begin{array}{c}28.6 \\
\text { to } \\
28.3 \\
\end{array}$ \\
\hline 2 & Male & 35 & 2.0 & 2 & 0.6 & $\begin{array}{c}36.9 \\
\text { to } \\
36.8\end{array}$ & $\begin{array}{c}34.3 \\
\text { to } \\
33.5\end{array}$ & $\begin{array}{c}28.3 \\
\text { to } \\
29.0\end{array}$ \\
\hline
\end{tabular}

Table 2. Experimental conditions

\begin{tabular}{|c|c|c|c|c|}
\hline $\mathrm{H} / \mathrm{C}$ system & $T_{a i}\left[{ }^{\circ} \mathrm{C}\right]$ & $T_{m r}\left[{ }^{\circ} \mathrm{C}\right]$ & $R H_{\text {in }}$ [\%] & $v_{a}[\mathrm{~m} / \mathrm{s}]$ \\
\hline Conventional & 22.5 & 22.5 & 60 & 0.1 \\
\hline LowEx & $18 \quad 27$ & $27 \quad 18$ & 60 & 0.1 \\
\hline $\begin{array}{l}\text { Conventional, } \\
\text { non-insulated case }\end{array}$ & 22.5 & 10 & 60 & 0.1 \\
\hline
\end{tabular}

The presented methodology combines the exergy analysis of individual thermal comfort conditions and measurements of energy use. It can be combined with the exergy and energy analysis of the whole heating system presented in a previous study by Dovjak et al. [2]. Additionally, exergy analysis enables us to consider the effect of room conditions created with different $\mathrm{H} / \mathrm{C}$ systems on separate parts of hbExB. And as the final result, the most efficient system from user and building point of view is selected.

\section{RESULTS AND DISCUSSION}

\subsection{Individual Thermal Comfort Conditions}

Table 3 presents the results of simulation of individual thermal comfort conditions for two users exposed to conditions created with conventional and LowEx system. The data show that hbExC rates and $P M V$ index vary among individuals for both systems, even if they are exposed to the same environmental
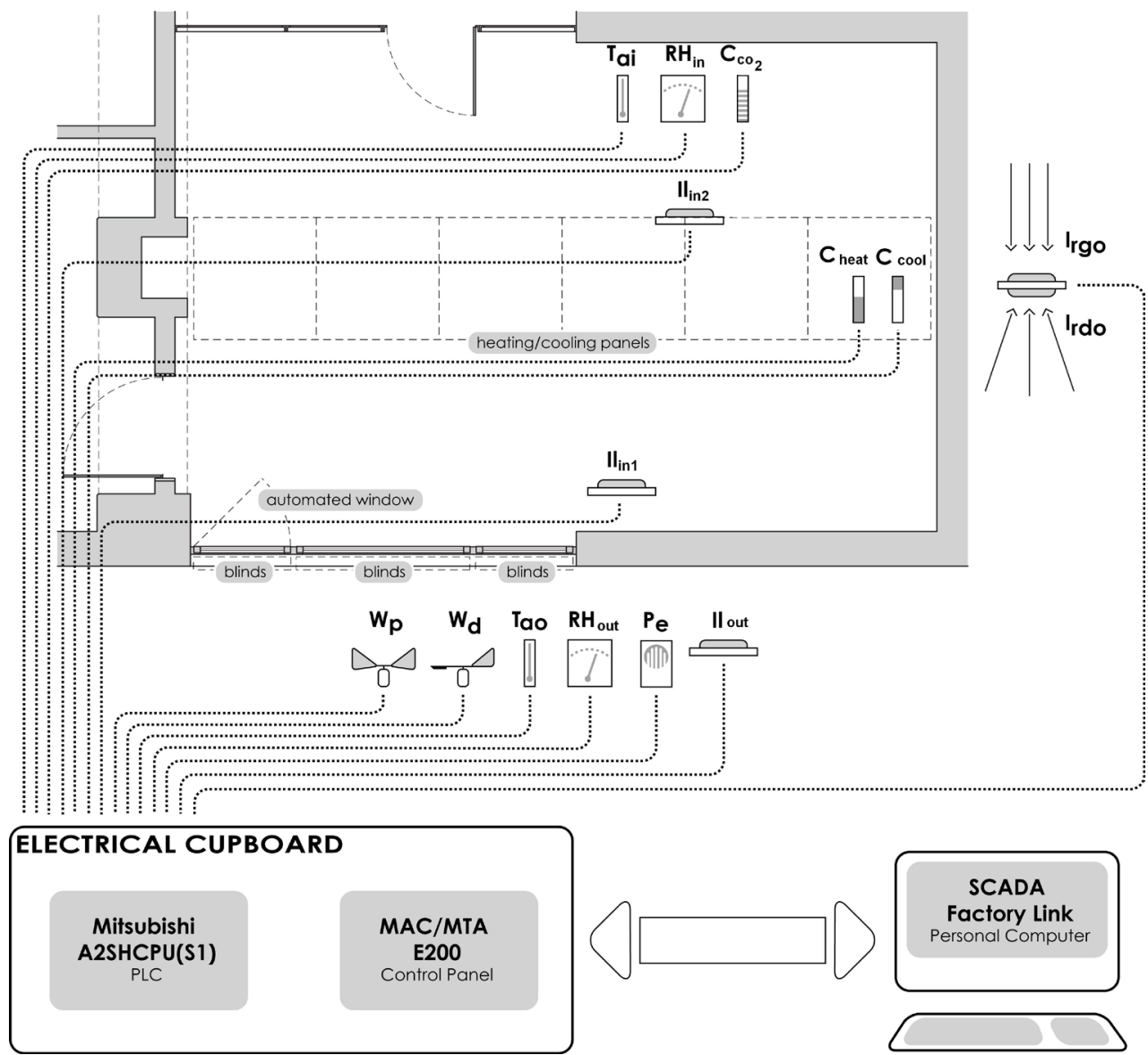

Fig. 4. Basic architecture of the ICSIE system; the presented sensor array consists of the following sensors: $T_{a i}$ is room air temperature, $T_{a 0}$ outdoor air temperature, $R H_{\text {in }}$ internal relative air humidity, $\mathrm{RH}_{\text {out }}$ external relative air humidity, $\left\|_{\text {in } 1} \&\right\|_{\text {in } 2}$ internal work plane illumination (workplace 1 and 2 ), II out external illumination, $\mathrm{C}_{\mathrm{CO} 2}$ concentration of $\mathrm{CO}_{2}, I_{\text {rgo }}$ direct solar radiation, $I_{\text {rdo }}$ reflected solar radiation, $W_{p}$ wind speed, $W_{d}$ wind direction, $P_{e}$ precipitation detection, $C_{\text {heat }}$ energy use for heating, $C_{\text {cool }}$ - energy use for cooling [28] 
conditions. Generally, more acceptable comfortable conditions ( $P M V$ closer to 0) can be created with LowEx system with higher surface temperatures than air temperatures $\left(T_{m r} 27^{\circ} \mathrm{C}, T_{a i} 18^{\circ} \mathrm{C}\right)$ compared with the conventional system.

Table 3. Human body exergy consumption (hbExC) rate and PMV index for two individual users in experimental conditions created with conventional and LowEx systems

\begin{tabular}{ccccc}
\hline User & $T_{a i}\left[{ }^{\circ} \mathrm{C}\right]$ & $T_{m r}\left[{ }^{\circ} \mathrm{C}\right]$ & hbExC rate $\left[\mathrm{W} / \mathrm{m}^{2}\right]$ & PMV index \\
\hline \multicolumn{5}{c}{ Conventional system } \\
\hline 1 & 22.5 & 22.5 & 2.38 & -0.2 \\
\hline 2 & 22.5 & 22.5 & 5.50 & 0.3 \\
\hline \multicolumn{5}{c}{ LowEx system } \\
\hline 1 & 18.0 & 27.0 & 2.23 & -0.1 \\
\hline 2 & 18.0 & 27.0 & 5.69 & 0.1 \\
\hline 1 & 27.0 & 18.0 & 3.52 & -0.2 \\
\hline 2 & 27.0 & 18.0 & 5.56 & 0.5 \\
\hline
\end{tabular}

However, more acceptable comfort conditions created with LowEx system $\left(T_{m r} 27{ }^{\circ} \mathrm{C}, T_{a i} 18{ }^{\circ} \mathrm{C}\right)$ do not always result in lower hbExC rates (User 1: $2.23 \mathrm{~W} / \mathrm{m}^{2}$; User 2: $5.69 \mathrm{~W} / \mathrm{m}^{2}$ ) than in the case of conventional system (User 1: $2.38 \mathrm{~W} / \mathrm{m}^{2}$; User 2: $5.50 \mathrm{~W} / \mathrm{m}^{2}$ ), as it was proven in previous studies on average test subjects (i.e. a 30 year old male, weighing $70 \mathrm{~kg}$, and $1.75 \mathrm{~m}$ tall, 1 met, $0.6 \mathrm{clo}$ ), or groups [21] to [27]. Individual differences and experimental conditions have significant influence on hbExC rate. For example, User 1 (1.1 met) has in conditions created with LowEx system $\left(T_{a i}<T_{m r}\right)$ lower hbExC rate and, vice versa, in conditions with $T_{a i}>T_{m r}$ or $T_{a i}=T_{m r}$ higher hbExC rate. Opposite situation appears for User 2 (2 met), where $T_{a i}<T_{m r}$ results in higher $\mathrm{hbExC}$ rate. The same conclusions were proven in studies [32] to [37]. Comfort conditions (PMV closer to 0$)$ result in lower $\mathrm{hbExC}$ rate only in case of users with metabolic rate around 1 met. Additionally, PMV values do not differ much between systems. They do not give us enough information to select which system creates more acceptable comfort conditions. All created conditions result in $P M V$ between -0.5 and +0.5 , which is generally acceptable as comfortable conditions. However, the difference in $P M V$ values is more significant if individual differences are considered and not systems. Additionally, $P M V$ values are not intended for individuals, but for groups, and do not have to match $A M V$ (actual mean vote) as it was proven in study [38].

Additional calculation for thermally non-insulated test room with conventional system $\left(T_{a i} 22.5{ }^{\circ} \mathrm{C}, T_{m r}\right.$ $10^{\circ} \mathrm{C}$ ) shows similar results. In those conditions users have the highest $\mathrm{hbExC}$ rates $\left(4.49 \mathrm{~W} / \mathrm{m}^{2}, 6.87 \mathrm{~W} / \mathrm{m}^{2}\right)$ with PMV -0.8 and 0 (Table 4). The whole hbExB for both users exposed to conditions created with conventional and LowEx system will be considered in the sequel.

Table 4. HbEXC rate and PMV index for two individual users and non-insulated case

\begin{tabular}{ccccc}
\hline User & $T_{a i}\left[{ }^{\circ} \mathrm{C}\right]$ & $T_{m r}\left[{ }^{\circ} \mathrm{C}\right]$ & hbExC rate $\left[\mathrm{W} / \mathrm{m}^{2}\right]$ & PMV index \\
\hline \multicolumn{5}{c}{ Conventional system, non-insulated case } \\
\hline 1 & 22.5 & 10 & 4.49 & -0.8 \\
\hline 2 & 22.5 & 10 & 6.87 & 0 \\
\hline
\end{tabular}

\subsubsection{Human Body Exergy Balance in Conditions Created with Conventional System}

Fig. 5 shows a numerical example of the whole hbExB for User 1 in experimental conditions created with the conventional system $\left(22.5{ }^{\circ} \mathrm{C} T_{a i}, 22.5{ }^{\circ} \mathrm{C}\right.$ $\left.T_{m r}, 60 \%\right)$. Input exergy presents thermal radiative exergy exchange between the human body and the surrounding surfaces and it influences the thermal comfort. Cool and warm radiant exergy absorbed by the whole skin and clothing surfaces is zero because $T_{a i}$ is equal to $T_{m r}$. Exergy of the inhaled humid air is also zero, because $R H_{i n}$ and $T_{a i}$ are equal to $R H_{\text {out }}$ and $T_{a o}$, respectively. The main input exergy $(100 \%)$ is presented by warm exergy generated by metabolism. This means that $3.32 \mathrm{~W} / \mathrm{m}^{2}$ of thermal exergy are generated by bio-chemical reactions inside the human body. It is influenced by the difference between $T_{c r}$ and $T_{a i}$ and by the difference between $T_{s k}$ and $T_{a i}$.

It is important to keep the body structure and function and to get rid of the generated entropy. Thus, $3.32 \mathrm{~W} / \mathrm{m}^{2}$ have to be released into ambient by radiation, convection, evaporation and conduction and present output exergy. As the moisture contained in the room air is not saturated, the water secreted from sweat glands evaporates into the ambient space. Warm/cool and wet/dry exergy contained in the resultant humid air containing the evaporated sweat is $0.20 \mathrm{~W} / \mathrm{m}^{2}(6.1 \%$ of output and consumed exergies). In our case it appears as warm and wet exergy, because skin temperature is higher than $T_{a i}$ and skin $R H$ is higher than $R H_{i n}$. Warm radiant exergy discharged from the whole skin and clothing surfaces emerges because of higher $T_{c l}$ than $T_{a i}$ and presents $0.29 \mathrm{~W} / \mathrm{m}^{2}$ ( $8.6 \%$ of output and consumed exergies). Exergy of $0.45 \mathrm{~W} / \mathrm{m}^{2}$ (13.5\% of output and consumed exergies) is transferred by convection from the whole skin and clothing surfaces into the surrounding air, mainly due to the difference between $T_{c l}$ and $T_{a i}$. Exergy consumption that presents the difference between 
exergy input, exergy stored and exergy output is 2.38 $\mathrm{W} / \mathrm{m}^{2}(71.7 \%$ of output and consumed exergies) for User 1 in the case of conventional system.

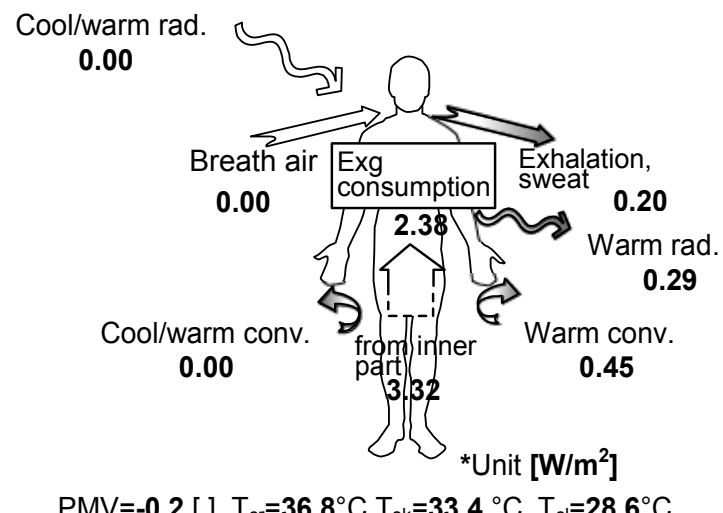

Fig. 5. Exergy balance of the human body for User 1 in experimental conditions created with the conventional system $\left(22.5^{\circ} \mathrm{C} T_{a i}\right.$ and $\left.22.5^{\circ} \mathrm{C} T_{m r}, 60 \% R_{i n}\right)$

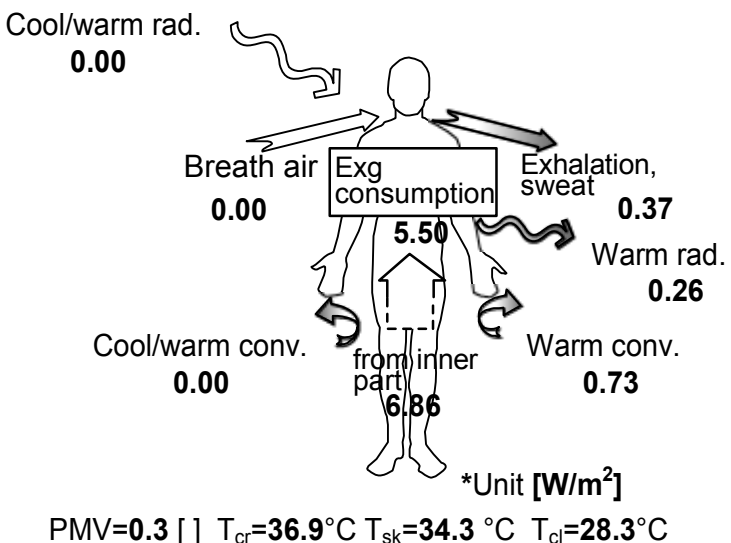

Fig. 6. Exergy balance of the human body for User 2 in experimental conditions created with the conventional system $\left(22.5{ }^{\circ} \mathrm{C} T_{a i}\right.$ and $\left.22.5{ }^{\circ} \mathrm{C} T_{m r}, 60 \% R H_{i n}\right)$

The whole human body exergy balance for User 2 in experimental conditions created with the conventional system differs from that for User 1 (Fig. 6). Higher metabolic level (2 Met) results in doubled value of metabolic thermal exergy as input exergy $\left(6.86 \mathrm{~W} / \mathrm{m}^{2}\right)$, mainly due to larger difference between $T_{c r}$ and $T_{a i}$ than in the case of User 1 in experimental conditions created with conventional system. Larger difference between $T_{c r}$ and $T_{a i}$ results also in higher output exergies with exhalation and evaporation of sweat $\left(0.37 \mathrm{~W} / \mathrm{m}^{2}\right)$ and warm convection transferred from the whole skin and clothing surfaces $(0.73$ $\mathrm{W} / \mathrm{m}^{2}$ ). Lower warm radiation discharged from the whole skin and clothing surfaces results due to lower difference between $T_{c l}$ and $T_{a i}$. Exergy consumption rate for User $2\left(5.50 \mathrm{~W} / \mathrm{m}^{2}\right)$ is much higher than for User $1\left(2.38 \mathrm{~W} / \mathrm{m}^{2}\right)$, mainly due to the doubled value of input exergy by metabolic thermal exergy.

An additional analysis of individual hbExB in thermally non-insulated test room with conventional system $\left(T_{a i} 22.5{ }^{\circ} \mathrm{C}, T_{m r} 10{ }^{\circ} \mathrm{C}\right)$ shows that lower surface temperatures result in lower temperatures of the skin and clothing surfaces and cause cool radiant exergy rate (for User 1 and User 2: $1.12 \mathrm{~W} / \mathrm{m}^{2}$ ) that is absorbed by the whole skin and clothing surfaces. Such conditions lead to discomfort [2] and [20].

\subsubsection{Human Body Exergy Balance in Conditions Created with LowEx System}

$\mathrm{HbExB}$ does not depend just on individual characteristics. The experimental conditions created with conventional or LowEx systems also have significant influence. For example, if User 1 was exposed to conditions $\left(18.0{ }^{\circ} \mathrm{C} T_{a i}, 27.0{ }^{\circ} \mathrm{C} T_{m r}\right.$, $60 \% R H_{\text {in }}$ ) created with LowEx system that resulted in the same operative temperature $\left(22.5^{\circ} \mathrm{C}\right)$ as in conventional system, the whole hbExB differed. Larger differences between $T_{c r}$ and $T_{a i}$, and $T_{s k}$ and $T_{a i}$ result in higher metabolic thermal exergy than in the case of conventional system $\left(4.28 \mathrm{~W} / \mathrm{m}^{2}, 87.6 \%\right)$. Higher $T_{m r}$ than $T_{a i}$ results in $0.61 \mathrm{~W} / \mathrm{m}^{2}(12.4 \%)$ of warm radiant exergy absorbed by the whole skin and clothing surfaces as input exergy. Larger difference between $T_{c l}$ and $T_{a i}$ causes higher output exergies with warm radiant exergy discharged from the whole skin and clothing surfaces $\left(0.91 \mathrm{~W} / \mathrm{m}^{2}, 18.6 \%\right)$, higher warm exergy transferred by convection $\left(1.45 \mathrm{~W} / \mathrm{m}^{2}\right.$, $29.6 \%$ ), and slightly higher exhalation and evaporation of sweat $\left(0.30 \mathrm{~W} / \mathrm{m}^{2}, 6.0 \%\right)$. Much higher output exergies and stored exergy result in lower hbExC rate $\left(2.23 \mathrm{~W} / \mathrm{m}^{2}, 45.7 \%\right)$ than in the conventional system (Fig. 7).

For User 2 in experimental conditions created with LowEx system similar conclusions can be made as for User 1: larger differences between $T_{c r}$ and $T_{a i}$ and $T_{s k}$ and $T_{a i}$ result in higher metabolic thermal exergy $\left(8.44 \mathrm{~W} / \mathrm{m}^{2}\right)$ than in conventional system $\left(6.86 \mathrm{~W} / \mathrm{m}^{2}\right)$. Higher $T_{m r}$ than $T_{a i}$ causes $0.61 \mathrm{~W} / \mathrm{m}^{2}$ of warm radiant exergy absorbed by the whole skin and clothing surfaces and higher output exergies than in conventional system (due to $T_{m r}>T_{a i}$ ). Warm exergy transferred by convection from the whole skin and clothing surfaces into the surrounding air is 2.10 $\mathrm{W} / \mathrm{m}^{2}$ (higher than in the conventional system due to larger difference between $T_{c l}$ and $T_{a i}$ ), exhalation and evaporation of sweat are $0.54 \mathrm{~W} / \mathrm{m}^{2}$ (higher due to 
larger difference between $T_{c r}$ and $T_{a i}$, and $T_{c l}$ and $T_{a i}$ ) and warm radiant exergy discharged from the whole skin and clothing surfaces is $0.72 \mathrm{~W} / \mathrm{m}^{2}$ (higher due to larger difference between $T_{c l}$ and $T_{a i}$ ). The difference between input exergies, stored exergy and output exergies is $5.69 \mathrm{~W} / \mathrm{m}^{2}$ and presents the $\mathrm{hbExC}$ rate for User 2 in the case of experimental conditions created with LowEx system (it is the highest because of the highest input exergies).

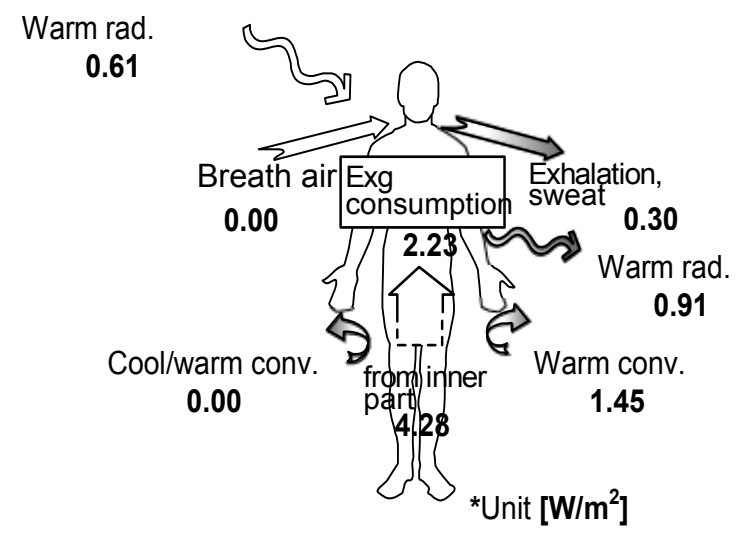

$P M V=-0.1[] \mathrm{T}_{\mathrm{cr}}=36.8^{\circ} \mathrm{C} \mathrm{T}_{\mathrm{sk}}=33.5^{\circ} \mathrm{C} \mathrm{T}_{\mathrm{Cl}}=29.0^{\circ} \mathrm{C}$

Fig. 7. Exergy balance of the human body for User 1 in experimental conditions created with the LowEx system $\left(18{ }^{\circ} \mathrm{C} T_{a i}\right.$ and $27{ }^{\circ} \mathrm{C} T_{m r}, 60 \% R H_{\text {in }}$ )

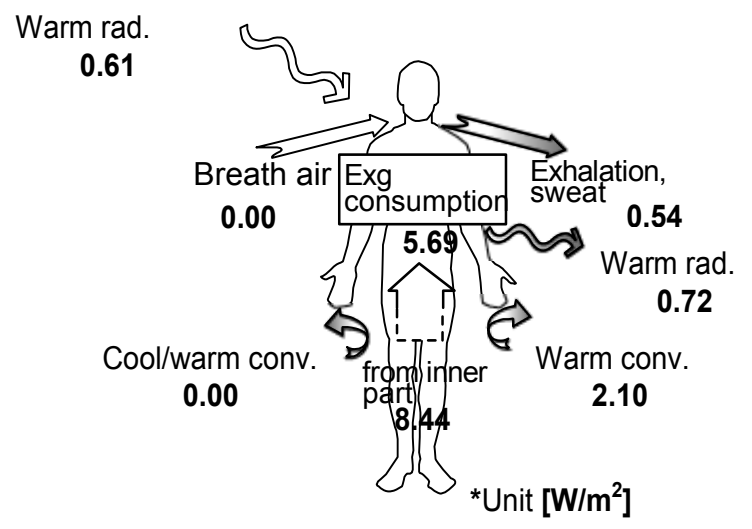

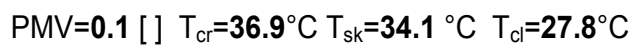

Fig. 8. Exergy balance of the human body for User 2 in experimental conditions created with the LowEx system $\left(18^{\circ} \mathrm{C} T_{a i}\right.$ and $\left.27{ }^{\circ} \mathrm{C} T_{m r}, 60 \% R H_{i n}\right)$

The exergy analysis of thermal comfort conditions shows that hbExB significantly differs between individuals and systems. Conditions created with conventional and LowEx system are comfort conditions for both users. Thermally not insulated case results in cool radiant exergy and discomfort conditions. Such conditions often appear in buildings with conventional systems. Warm radiant exergy emitted from LowEx system and absorbed by the whole skin and clothing surfaces has positive effect on thermal comfort conditions, as it was proven in studies [32] to [37]. LowEx system connected with ICsIE system enables to set up the combination between $T_{a i}$ and $T_{m r}$, which results in optimal conditions for the individual user.

\subsection{LowEx vs. Conventional System and Measured Energy Use}

Energy use was measured for the same test room equipped with LowEx and conventional system in various time periods. Energy use for heating was measured for winter period $(\mathrm{H}$ winter: 5.03. to $23.03 .2010,447$ heating hours) and summer period (18.06. to $24.06 .2010,81$ heating hours) and it presents overall 528 heating hours. Heating was performed also for summer period (H summer: 81 heating hours), because in many occupied spaces with special procedures higher temperatures may be required. Energy use for cooling was measured for summer period 10.06. to 24.06 .2010 and 5.07. to 10.07.2010 and presents overall 453 cooling hours. The measured energy use is presented in MJ for heating or cooling as shown in Table 5.

Table 5. Measured energy use for heating and cooling [MJ]

\begin{tabular}{cccc}
\hline $\mathrm{H} / \mathrm{C}$ system & $T_{a 0}\left[{ }^{\circ} \mathrm{C}\right]$ & $T_{a i}\left[{ }^{\circ} \mathrm{C}\right]$ & Energy use [MJ] \\
\hline \multicolumn{4}{c}{ Conventional system } \\
\hline H winter & -2.6 & 23.7 & 2.95 \\
\hline H summer & 13.2 & 25.4 & 1.33 \\
\hline C summer & 20.0 & 25.3 & 3.24 \\
\hline C summer & 26.4 & 20.9 \\
\hline \multicolumn{4}{c}{ LowEx system } \\
\hline H winter & -2.6 & 23.3 \\
\hline H summer & 13.5 & 25.5 & 0.97 \\
\hline C summer & 19.3 & 25.7 & 1.20 \\
\hline C summer & 26.5 & 20.7 & 2.02 \\
\hline
\end{tabular}

The measured energy use for heating was by 11 to $27 \%$ lower for LowEx system than for conventional system. The energy use for cooling was by 41 to $62 \%$ lower for LowEx system. The overall energy use for the whole measured cooling period (453 cooling hours) was 518 MJ (1.15 MJ average energy use per cooling hour) for LowEx system, and $1314 \mathrm{MJ}$ (2.90 MJ average energy use per cooling hour) for conventional system. The reason for a relatively low efficiency of the LowEx system during the experiment was a small ceiling surface area that was heated and cooled, i.e. $25 \%$ of ceiling surface. The calculated energy use for heating in case of four times larger 
surface area of panels was $40 \%$ lower energy use than for conventional system.

\section{CONCLUSIONS}

The results of the simulation of individual thermal comfort conditions show that human body hbExC rates and $P M V$ index vary between experimental conditions created with conventional and LowEx systems. $P M V$ index does not give us enough information to conclude which system is more efficient from the thermal comfort point of view. The results of the whole $\mathrm{hbExB}$ give detailed information on the effect of individual characteristics and experimental conditions on individual parts of hbExB. Previous studies on average test subjects show that comfort conditions result in lower hbExC rate. The results of our simulation on individual users showed that more comfortable conditions (PMV closer to 0) do not always result in lower hbExC rate. Individual characteristics affect considerably every part of hbExB.

Both systems can create comfort conditions, but the room has to be thermally insulated. LowEx system connected with ICsIE enables the creation of thermally comfortable conditions with regulated individual parts of hbExB with set $T_{a i}$ and $T_{m r}$. The measured energy use for heating was by 11 to $27 \%$ lower for LowEx system than for conventional system. The energy use for cooling was by 41 to $62 \%$ lower for LowEx system. The reason for relatively low efficiency of LowEx system during the experiment was small ceiling surface area that was heated $(25 \%)$. For applications in the real environment a large part of the ceiling has to be covered with panels. The calculated energy use for heating in the case of a four times larger surface area of panels is $40 \%$ lower energy use. The presented approach of reciprocal consideration of individual thermal comfort and building energy use is important for the future design of heating and cooling systems for the application in near zero energy buildings.

\section{ACKNOWLEDGMENTS}

COST Action C24 Analysis and design of innovative systems with LowEx for application in build environment, International Energy Agency; Energy Conservation In Buildings And Community Systems; Annex 49; Laboratory of Building environment, Tokyo City University; Department of Civil Engineering, Technical University of Denmark; University of Ljubljana, Faculty of Civil and Geodetic
Engineering; Ministry of Higher Education, Science and Technology, Republic of Slovenia.

\section{REFERENCES}

[1] Directive 2010/31/EU. (2010). Directive of the European Parliament and of the Council on the energy performance of buildings (recast). European Commission, Brussels.

[2] Dovjak, M., Shukuya, M., Olesen, B.W., Krainer, A. (2010). Analysis on exergy consumption patterns for space heating in Slovenian buildings. Energy Policy, vol. 38, no. 6, p. 2998-3007, DOI:10.1016/j. enpol.2010.01.039.

[3] Rant, Z. (1955). Energy value and pricing. Strojniški vestnik - Journal of Mechanical Engineering, vol. 1, no. 1, p. 4-7.

[4] Galović, A., Ferdelji, N., Mudrinić, S. (2010). Entropy generation and exergy efficiency in adiabatic mixing of nitrogen and oxygen streams of different temperature and environmental pressures. Strojniški vestnik Journal of Mechanical Engineering, vol. 56, no. 12, p. 817-822.

[5] Takahashi, H. (1979). Exergy. Applied Physics, vol. 48, no. 8 , p. $49-54$.

[6] Shukuya, M., Hammache, A. (2002). Introduction to the concept of exergy for a better understanding of low temperature heating and high temperature cooling systems. IEA Annex 37, from http://www.vtt.fi/inf/pdf/ tiedotteet/2002/T2158.pdf, accessed on 2011-06-15.

[7] Dovjak, M., Shukuya, M., Olesen, B.W., Krainer, A. (2010). Innovative design of renewable energy technology systems for heating and cooling in sustainable buildings. Renewable Energy, Conference Proceedings, p. 1-4.

[8] International Energy Agency. (2006). Low Exergy heating and Cooling of Buildings, Annex 37, from http://www.vtt.fi/rte/projects/annex37/Index.htm, accessed on 2011-06-15.

[9] Poredoš, A., Kitanovski, A. (2002). Exergy loss as a basis for the price of thermal energy. Energy Conversion and Management, vol. 43, no. 16, p. 21632173, DOI:10.1016/S0196-8904(01)00156-X.

[10] Poredoš, A. (2000). The energy efficiency of district cooling for space conditioning. Strojniški vestnik Journal of Mechanical Engineering, vol. 46, no. 8, p. 557-563.

[11] Ljubenko, A., Poredoš A., Zager, M. (2011). Effects of hot-water-pipeline renovation in a district heating system. Strojniški vestnik - Journal of Mechanical Engineering, vol. 57, no. 11, p. 834-847, DOI:10.5545/ sv-jme.2010.227.

[12] Krainer, A., Perdan, R., Krainer, G. (2007). Retrofitting of the Slovene ethnographic museum. Bauphysik, vol. 29, no. 5, p. 350-365, DOI:10.1002/bapi.200710045.

[13] Olesen, B.W. (2008). Radiant floor cooling systems. ASHRAE Journal, vol. 9, p. 16-22. 
[14] Košir, M., Krainer, A., Dovjak, M., Perdan, R., Kristl, Ž. (2010). Alternative to the Conventional Heating and Cooling Systems in Public Buildings. Strojniški vestnik - Journal of Mechanical Engineering, vol. 56, no. 9, p. 575-583.

[15] Sakulpipatsin, P. (2008). Exergy Efficient Building Design. Doctoral thesis. Delft University of Technology, Delft.

[16] Schata, M., Elixman, J.H., Jorde, W. (1990). Evidence of heating systems in controlling house-dust mites and moulds in the indoor environment. Indoor Air ' 90 Conference Proceedings, p. 577-581.

[17] Lengweiler, P., Nielsen, P.V., Moser, A. (1997). Deposition and resuspension of Particles. Healthy Buildings Conference Proceedings, p. 501-502.

[18] Isawa, K., Komizo T., Shukuya, M. (2003). The relationship between human-body exergy consumption rate and a combination of indoor air temperature and mean radiant temperature. Transactions of Architectural Institute of Japan, no. 570, p. 29-35.

[19] Shukuya, M. (2006). Comfortable high-performance and low exergy built environment. The International Energy Agency, Energy Conservation in Buildings and Community Systems Conference Proceedings, p. 893898.

[20] Shukuya, M., Saito, M., Isawa, K., Iwamatsu, T., Asada, H. (2010). Human body exergy balance and thermal comfort. Working Report of The International Energy Agency, Energy Conservation in Buildings and Community Systems, Annex 49. Fraunhofer.

[21] Shukuya, M., (2009). Exergy concept and its application to the built environment. Building and Environment, vol. 44, no. 7, p. 1545-1550, DOI:10.1016/j. buildenv.2008.06.019.

[22] Prek, M. (2004). Exergy analysis of thermal comfort. International Journal of Exergy, vol. 1, no. 2, p. $303-$ 315, DOI:10.1504/IJEX.2004.005559.

[23] Prek, M., Butala, V. (2010). Principles of exergy analysis of human heat and mass exchange with the indoor environment. International Journal of Heat and Mass Transfer, vol. 53, no. 25/26, p. 5806-5814, DOI:10.1016/j.ijheatmasstransfer.2010.08.003.

[24] Simone, A., Kolarik, J., Asada, H., Dovjak, M., Schellen, L., Iwamatsu, T., Shukuya, M., Olesen, B.W. (2011). A relation between calculated human body exergy consumption rate and subjectively assessed thermal sensation. Energy and Buildings, vol. 43, no. 1, p. 1-9, DOI:10.1016/j.enbuild.2010.08.007.

[25] Iwamatsu, T., Asada, H. (2009). A calculation tool for human-body exergy balance. The International Energy Agency, Energy Conservation in Buildings and Community Systems Annex 49 Newsletter, no. 6, p. 4-5. Fraunhofer.

[26] Tokunaga, K., Shukuya, M. (2011). Human-body exergy balance calculation under un-steady state conditions. Building and Environment, vol. 46, no. 11, p. 2220-2229, DOI:10.1016/j.buildenv.2011.04.036.

[27] Schweiker, M., Shukuya, M. (2012). Adaptive comfort from the viewpoint of human body exergy consumption. Building and Environment, in press, DOI:10.1016/j.buildenv.2011.11.012.

[28] Košir, M. (2008). Integrated regulating system of internal environment of the basis of fuzzy logic use. Doctoral thesis. University of Ljubljana, Ljubljana.

[29] Trobec-Lah, M. (2003). Harmonisation of thermal and daylight fluxes with fuzzy logic. Doctoral thesis. University of Ljubljana, Ljubljana.

[30] Košir, M., Krainer A., Kristl, Ž. (2012). Integral control system of indoor environment in continuously occupied spaces. Automation and Construction, vol. 21, p. 199209, DOI:10.1016/j.autcon.2011.06.004.

[31] Kristl, Ž., Košir, M., Trobec Lah, M., Krainer, A. (2008). Fuzzy control system for thermal and visual comfort in building. Renewable Energy, vol. 4, no. 33, p. 694-702, DOI:10.1016/j.renene.2007.03.020.

[32] Dovjak, M., Shukuya, M., Olesen, B.W., Krainer, A. (2010). Innovative design of renewable energy technology systems for heating and cooling in sustainable buildings. Renewable Energy, Conference Proceedings, p. 1-4.

[33] Dovjak, M., Asada, H., Iwamatsu, T., Shukuya, M., Olesen, B.W., Krainer, A. (2011). Lowex vs. conventional systems: User/building/environment. Exergy, Life Cycle Assessment, and Sustainability 2 Conference Proceedings, p. 1-8

[34] Dovjak, M., Simone, A., Kolarik, J., Asada, H., Iwamatsu, T., Schellen, L., Shukuya, M., Olesen, B.W., Krainer, A. (2011). Exergy analysis: The effect of relative humidity, air temperature and effective clothing insulation on thermal comfort. Exergy, Life Cycle Assessment, and Sustainability 2, Conference Proceedings, p. 1-8.

[35] Dovjak, M., Shukuya, M. (2011). Integral control of hospital environment. IEEE, Conference Proceedings, p. 1-4

[36] Dovjak, M., Shukuya, M., Krainer, A. (2011). Towards zero energy buildings with conventional or renewable energy technology systems? International Renewable Energy Conference Proceedings, p. 1-6.

[37] Dovjak, M., Shukuya, M., Krainer, A. (2011). Solar heating and cooling system for thermal comfort conditions and lower building energy use. The International Solar Energy Society Conference Proceedings, p. 1-10.

[38] Ealiwa, A., Taki, A. H., Howarth, A.T., Seden, M.R. (2001). An investigation into thermal comfort in the summer season of Ghadames, Libya. Building and Environment, vol. 36, no. 2, p. 231-237, DOI:10.1016/ S0360-1323(99)00071-2. 